\title{
Original article \\ Fear of falling and self-perception of health in older participants and non-participants of physical activity programs
}

\author{
Carolina Kruleske da Silva \\ Northern University of Paraná, Brazil \\ Celita Salmaso Trelha \\ State University of Londrina, Brazil \\ Rubens Alexandre da Silva Junior \\ Northern University of Paraná, Brazil
}

\begin{abstract}
Fear of falling, self-perception of health, and participation in physical activity programs have been associated with several variables related to health and performance in older adults. The purpose of this study was to evaluate self-perception of health and fear of falling in older adult participants and non-participants of physical activity programs, and to verify the relationship between these variables. A total of 40 healthy but sedentary older adults, and 45 physically active older adults were assessed through the Falls Efficacy Scale International-Brazil (FES-I) and a questionnaire that measured their self-perception of health. The older adults that did not participate in regular physical activity programs presented higher scores of fear of falling, which, in turn, is associated with an increase of risk for falls. Moreover, older adults, participants in regular physical activity programs exhibited a more positive health perception than did the non-participants. Also, non-participants of physical activity programs perceived their health status as being poor or very poor as well as expressing great concern about falling compared to those who considered their health as excellent, good or regular. The results of this study have important implications for making clinical decisions in prevention or rehabilitation of older people, and they justify recommendations to the public health system.
\end{abstract}

Keywords: health and aging, physical activity, fear of falling

Resumo- - "Medo de cair e autopercepção de saúde em indivíduos idosos participantes e não participantes em programas de atividade física." Medo de cair, autopercepção da saúde e participação em programas de atividade física têm sido associados a diversas variáveis relacionadas à saúde e ao desempenho de indivíduos idosos. O objetivo deste trabalho foi avaliar a autopercepção da saúde e o medo de cair em indivíduos idosos participantes e não participantes de programas de atividade física, e verificar a associação entre estas variáveis. Foram avaliados indivíduos idosos saudáveis, sendo 40 sedentários e 45 participantes de programas de atividade física regular, por meio da Falls Efficacy Scale International-Brasil (FES-I) e do questionário de autopercepção subjetiva da saúde.Indivíduos idosos não participantes de programas de atividade física regular apresentaram maior pontuação na avaliação do medo de cair, o que pode estar associado a um maior risco de quedas. Os indivíduos que participavam de programas de atividade física regular demonstraram melhor percepção da saúde do que os não participantes. Além disso, os indivíduos não participantes de programas de atividade física regular percebiam sua saúde como ruim ou péssima e apresentavam maior preocupação em cair, quando comparados com aqueles que consideravam sua saúde como ótima, boa ou regular. Estes Os resultados deste estudo têm implicações relevantes para a tomada de decisões clínicas na prevenção ou reabilitação de pessoas idosas, e justificam recomendações ao sistema de saúde pública.

Palavras-chaves: saúde e envelhecimento, atividade física, medo de cair

Resumen - "El miedo de caer y la autopercepción de la salud en las personas mayores que participan y que no participan en programas de actividad física." El miedo de caer, la percepción de salud y la participación en programas de actividad física se han asociado con diversas variables relacionadas con la salud y el rendimiento de las personas de edad avanzada. El objetivo de este estudio fue evaluar la percepción de la salud y el miedo de caer en los participantes mayores y los no participantes en programas de actividad física, y la asociación entre estas variables. Se evaluaron 40 adultos mayores sanos, pero sedentarios y 45 fisicamente activos, a través de la Falls Efficacy Scale International-Brasil (FES-I) y de lo cuestionario de percepción subjetiva de la salud. Tercera 
edad que no participan en los programas regulares de actividad física mostraron una mayor preocupación por la caída, lo que indica un mayor miedo a caer, y que se asocia con un mayor riesgo de caídas. Por otra parte, las personas mayores participantes en el programa de actividad física regular tienen una mejor percepción de salud que los no participantes. Además, los no participantes en el programa de actividad física regular percibían su salud como mala o muy mala y tenían una mayor preocupación por la caída que los que calificaron su salud como excelente, bueno o regular. Los resultados de este estudio tienen implicaciones importantes para la toma de decisiones clinicas en la prevención y rehabilitación de las personas mayores, y justifican las recomendaciones para el sistema de salud pública.

Palabras claves: la salud y el envejecimiento, actividad física, miedo de caer

\section{Introduction}

The increase of the older population is a worldwide phenomenon and, in Brazil changes in the population demographics are also a reality. The number of scientific studies related to the topic of aging has increased each year, which illustrates the growing interest in the health of older adults.

The Brazilian Institute of Geography and Statistics (2009) pointed out that, in Brazil, adults over sixty years of age already represent about $11 \%$ of the total population, and it is further estimated that, for the year of 2050, Brazil will have the fifth highest population of older people in the world. The growth of the older population in the Brazilian city of Londrina, State of Paraná, agrees with the national and global parameters, representing $12.1 \%$ of the total population, according to the report of the Municipal Secretary of Aging Affairs (2010).

Falls and fear of falling are among the biggest concerns associated with the aging process. These two factors are the major causes of loss of autonomy and independence in older individuals. Due to clinical relevance and complexity of consequences, fear of falling has become a serious health problem for older people (Kempen et al., 2009; Perracini \& Ramos, 2002; Scheffer et al., 2008; Silvestre \& Costa Neto, 2003).

Given these considerations, there is a growing concern in health professionals to develop strategies to better control falls and the fear of falling in older adults. One of the strategies for preventing and managing these factors is to motivate older people to participate in regular physical activity programs, which have been highly prioritized in public policies (Gerez, Velardi, Camera, \& Miranda, 2010). Physical activity is associated with a number of health benefits and is an opportunity to manage and prevent diseases and disabilities in older adults. Borges and Moreira (2009) observed that physical activity improves the autonomy of older people in their performance of daily and instrumental activities. In their study, active older adults showed better autonomy than did a sedentary group. These authors also suggested that a sedentary lifestyle accelerates the decline of functional capacities, leading to the loss of independence in the performance of daily activities.

Fear of falling has also been identified as an important factor for the abandonment of physical activity programs by older people. Consequences of physical inactivity include social isolation, limitations in functional activities, and poor quality of life (Dalbaere, Close, Brodaty, Sachdev, \& Lord, 2010; Lopes, Costa, Santos, Castro, \& Bastone, 2009). Fear of falling has been reported to occur in $12 \%$ to $65 \%$ of those with no history of falls, and in $29 \%$ to $92 \%$ for those with history of falls (Jorstad, Hauer, Becker, \& Lamb, 2005). Unfortunately, this psychosomatic phenomenon of fear can be linked to several changes in the physical and mental health conditions in older adults, which, in turn, can lead to chronic diseases, deficits in balance and gait, muscle weakness, cognitive impairment, and anxiety and depression (Dalbaere et al., 2010; Lopes et al., 2009; Legters, 2002; Lord, Menz, \& Tiedemann, 2003).

Few studies have investigated these two phenomena together. Some instruments have been developed to help to prevent falls. The Falls Efficacy Scale International, published by the Network Europe-Profane in 2005, is an evaluation scale of self efficacy related to falls. This scale is a reliable instrument for assessing the fear of falling in older adults (internal consistency: $\alpha$-Cronbach $=0.96$, test-retest reliability ICC $=0.96$ ) (Yardley et al., 2005). Recently, the scale was translated and adapted to Portuguese, and showed reliable results as those found for the original version (internal consistency: $\alpha=0.93$ and reliability $\mathrm{ICC}=0.84$ and 0.91 intra- and inter-observers, respectively). Therefore, this instrument was adopted by Camargo, Dias, Dias, and Freire (2010) to evaluate fear of falling in older Brazilians.

Silva, Duarte, and Arantes (2011) found that the risk for falls is greater in older women with lower activity levels. Risk for fall also can be related to variables that are not directly affected by physical activity, such as selfperception of health and fear of falling. Studies with clinical applications have evaluated self perception of health and have associated it with several variables in older individuals. However, no studies have associated measures of self perception of health with fear of falling in this population. De Vitta, Neri, and Padovani, (2006) showed that sedentary older individuals have scores slightly lower in their selfperception of health when compared to active individuals. They suggested that this result is due to effects of engagement in physical activity on health conditions that are linked to physical and psychological factors. Self 
perception of health, although subjective, is easily measured, and can be associated with other objective measures of physical, cognitive, and emotional health. Self perception of health can also be associated with morbidity, mortality, and frequency of health services procurement (Alves \& Rodrigues, 2005; Silva \& Menezes, 2007).

Based on these considerations, this study predicted that regular participation in physical activity programs designated for older adults may affect their self-perception of health and fear of falling. The lack of participation in physical activities may result in poorer quality of life and increased risk for developing health disorders. Although there are several studies related to engagement in physical activity by older people in the literature, the associations with fear of falling and self-perception of health are still in debate. Thus, the main purpose of this study was to evaluate the self perception of health and fear of falling in older people participants and non-participants of regular physical activity programs. A second purpose was to assess the relationship between the perceived health condition and the risks for falls-based on fear of falling in both groups (participants and non-participants of physical activity programs).

\section{Method}

\section{Participants}

The participants were selected by convenience from the archives of the Family Health Program at the Basic Health Units (BHU), and then were invited to participate as volunteers. The sample comprised of participants drawn from a larger group part of a research project titled "Perception of fear and risk of falls in older individuals in the community" of the BHU in the city of Londrina, State of Paraná, Brazil. From the 52 BHU of the city, thirteen were excluded because they were part of "patrimonies" (n $=3)$, districts $(n=9)$ and indigenous reserves $(n=1)$. Of the 39 remaining $\mathrm{BHU}$, nine were randomly selected in order to determine the sample in this study. Ten older individuals were recruited from each BHU. The final sample was of 90 participants.

Individuals over 60 years old were included in the study. They were residents in the community. They were independent for walking, used no aid or assistive devices to walk (e.g., crutches and canes). We did not include institutionalized older adults suspected of cognitive impairment-based on mini-mental state examination by Brucki, Nitrini, Caramelli, Bertolucci, and Okamoto (2003).

All participants were informed about the experimental protocol and the potential risks involved in the study, and gave written consent before participation. The study was approved by the local ethics committee (Universidade Estadual de Londrina \#29/10) in agreement with the National Health Council (1996). The study was also approved by the Secretary of the City Hall of Londrina (CD003/2010).

\section{Procedure}

The study used a transversal design. Interviews were conducted at home with pre-scheduled visits, from June to September 2010. The older participants answered a questionnaire in order to characterize the sample (anthropometric data, health status, cognitive status, and history of falls). Fear of falling was evaluated by the Falls Efficacy Scale - International - Brazil (FES-I) (Camargo et al., 2010) questionnaire. FES-I screens for the possibility of falling in 16 daily living activities, including outdoor activities and social participation. The total score of the questionnaire ranges from 16-64 points so that the highest score $(\geq 23)$ indicates greater risks for falls, while scores greater than 31 points indicate high risk for recurrent falls (Freire, 2009; Camargos et al., 2010).

Self-perception of health was evaluated by the question "How do you consider your health lately?" Answers were bassed on a five-item scale: "excellent," "good," "regular," "poor" and "very poor" (Silva \& Menezes, 2007). In addition, information of medical diagnosis about health conditions was self-reported using a checklist: hypertension, hypercholesterolemia, diabetes, visual impairment and hearing impairment. History of falls in the last year and current routine of physical activity were also registered.

After the interviews, participants were divided in two groups: the first group consisted of individuals $(n=45)$ who were engaged in regular physical activity programs that included two $45 \mathrm{~min}$-sessions per week, which included neuromotor exercises, supervised or not, for at least three months. The second group $(n=40)$ was comprised of older adults who did not participate in regular physical activity programs.

\section{Statistical analysis}

Statistical analysis was performed using SPSS 15.0 for Windows. Descriptive statistical measures of central tendency (mean and median) and dispersion (standard deviation and interquartile range $-1^{\text {st }}$ and $3^{\text {rd }}$ quartile) were used for numerical variables, whereas the absolute and relative frequency was used for categorical variables. According to Shapiro-Wilk test, the data were not normally distributed, therefore nonparametric tests were used. Mann-Whitney test was used to compare differences between-group (active older adults versus sedentary older adults) in the FES-I scores. Kruskal-Wallis test followed by the Mann-Whitney test with pair-wise comparisons was performed to detect differences in the FES-I scores between the two groups classified by their self-perception of health. Finally, the relationship between the FES-I score and self-perception of health for each group (active older adults versus sedentary older adults) was analyzed using the Chi-square test $\left(\chi^{2}\right)$. The significance level adopted for all analysis was $\alpha=.05$. 
Table 1. Characterization of older individuals enrolled in the study

\begin{tabular}{|c|c|c|c|c|}
\hline & \multirow{2}{*}{ Total } & \multicolumn{2}{|c|}{ Physical Activity } & \multirow{2}{*}{$p$ values } \\
\hline & & No & Yes & \\
\hline \multicolumn{5}{|l|}{ Age $^{\#}$} \\
\hline Average (DP) & $72.3(8.22)$ & $72.9(8.60)$ & $71.7(7.91)$ & 0.69 \\
\hline \multicolumn{5}{|c|}{ Mini-exam of mental state } \\
\hline Total Score & $26.7(3.05)$ & $26.3(3.13)$ & $27.1(2.91)$ & 0.16 \\
\hline \multicolumn{5}{|l|}{ Health conditions* } \\
\hline Hypertension & $64(75.3 \%)$ & $33(38.8 \%)$ & $31(36.5 \%)$ & 0.80 \\
\hline Diabetes & $31(36.4 \%)$ & $16(18.8 \%)$ & $15(17.6)$ & 0.86 \\
\hline Hypercholesterolemia & $29(34.5 \%)$ & $12(14.3 \%)$ & $17(20.2 \%)$ & 0.30 \\
\hline Visual impairment & $34(20 \%)$ & $17(20 \%)$ & $17(20 \%)$ & - \\
\hline Hearing impairment & $21(24.7 \%)$ & $13(15.3 \%)$ & $8(9.4 \%)$ & 0.27 \\
\hline \multicolumn{5}{|l|}{ History of falling* } \\
\hline Fallings in the last year & $39(45.9 \%)$ & $19(22.4 \%)$ & $20(23.25 \%)$ & 0.87 \\
\hline
\end{tabular}

\section{Results}

Five older adults were excluded form the analysis because they showed low mini-mental score. The total number of participants was 85 (45 participants of physical activity programs and 40 non-participants). Both groups were homogeneous in their anthropometric and health clinical condition measures (see Table 1).

Results from the FES-I scores for the older adults participants of physical activity program $(n=45)$ showed a median score of 20 ( 17 and 24 for $1^{\text {st }}$ and $3^{\text {rd }}$ quartiles, respectively), indicating minor risk for falls related to fear of falling when compared to the non-participants $(n=40)$, median score of 23 (19 and 30 for $1^{\text {st }}$ and $3^{\text {rd }}$ quartiles, respectively). According to the Mann-Whitney test, these differences between-groups for the FES-I values were statistically significant $(U=587 ; z=2.76 ; p=0.006)$.

Participants in regular physical activity programs perceived their health relatively better than nonparticipants, with 39\% referring as excellent or good health, and $3.5 \%$ as poor or very poor. On the other hand, $24 \%$ of the non-participant stated qualified their health as being excellent or good, and $9.4 \%$ as being poor or very poor.

When the groups were assessed for the potential risk to experience falls (FES-I score $\geq 23$ ), a significant association between participation in physical activity and lower risk of falls $\left(\chi^{2}=4.95 ; p=0.03\right)$ was observed.

The relationship between self-perceived health and physical activity was assessed separately for three subgroups separated by their self-perceived health results: excellent or good (G1), regular (G2), and poor or very poor (G3). We found a significant difference $\left(\chi^{2}=5.53 ; p=\right.$ 0.02 ) for these groups: $73.3 \%$ of older people who were engaged in physical activity indicated their health as excellent or good, and only $6.6 \%$ as poor or very poor (see Figure 1). Among the older adults, non-participants of physical activity programs, $50 \%$ perceived their health as excellent or good and $20 \%$ as poor or very poor.

The relationship between FES-I score and self-rated health was also significant across these groups $\left(\chi^{2}=18.84\right.$; $p=0.002)$. In order to identify these differences between groups (participants and non-participants of physical activity program), Mann-Whitney test were calculated and showed that older adults participants were significant different than sedentary group, rating their health as poor or very poor ( $p=0.048$; Figure 2 ).

For the individuals who regularly participated in physical activity programs, the Kruskal-Wallis analysis showed no significant differences in the FES-I score between the subgroups G1 (excellent and/or good health condition), G2 (regular health condition) and G3 (poor and/or very poor health condition) $\left(\chi^{2}=3.02 ; p=0.22\right)$.

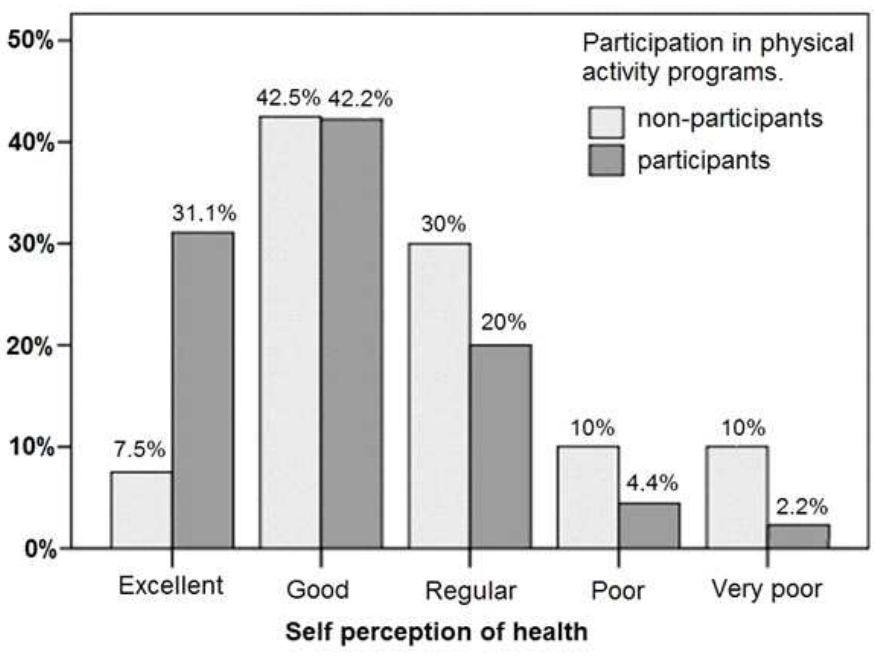

Figure 1. Self-perceived health by the older participants and nonparticipants of physical activity programs. 


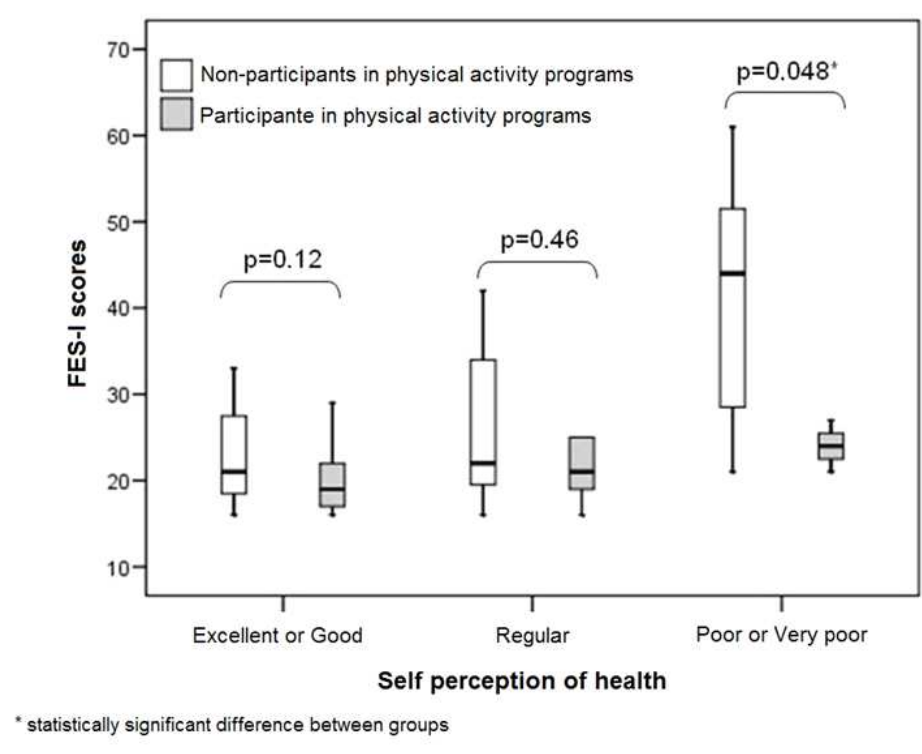

Figure 2. Differences between-groups in the FES-I scores relative to perceived health status.

Among the sub-groups of non-participants in physical activity programs, differences in the FES-I score were observed $\left(\chi^{2}=10.46 ; p=0.005\right)$, with significant differences between subgroups G1 (excellent and/good) and G3 (poor and/or very poor) $(p=0.001)$, and between G2 (regular) and G3 $(p=0.03)$.

\section{Discussion}

The present study investigated self-perception of health and fear of falling in older participants and non-participants of regular physical activity programs. The main results showed that, among the participants who took part in regular physical activity programs, lower risk for falls was associated with a better perception about health status relative to the group of non-participants in physical activity programs.

As expected, a positive perception of health is related to a better quality of life for older people. Indeed, selfperceived health has strong association with mortality, morbidity, health services procurement, demographic and socioeconomic characteristics, chronic diseases and disability (Alves \& Rodrigues, 2005; Silva \& Menezes, 2007). This health indicator is also relevant to explain adherence of individuals in preventive practices and for medical recommendations (Silva \& Menezes, 2007). This indicator may also explain adherence to specific programs of physical exercises or choices of active lifestyles.

Older individuals who experience fear of falling usually restrict some their physical activities, which will result in social isolation, limitations of functional conditions, and consequently lead to poor lifestyle with potential loss of autonomy (Dalbaere et al., 2010; Jorstad et al., 2005; Yardley \& Smith, 2002). In the present study, older adults who participated in regular physical activity programs presented lower fear of falling as compared to the sedentary older group (non-participant). In fact, $31 \%$ of older adults who practiced regular physical activity perceived their health as excellent, compared to $7.5 \%$ of the sedentary group. Similar to the study conducted by Silva and Menezes (2007), the present study assessed self-perceived health in three categories (G1, G2 and G3): "excellent or good," "regular" and "poor or very poor." Older people who took part in regular physical activity programs perceived their health as "excellent" or "good" while those who did not engage themselves in physical activity programs have lower FES-I scores, therefore, showing greater concern about falling and increased risk for falls. Also, older people who were engaged in regular physical activity programs and perceive their health as poor or very poor tended to have higher scores on the FES-I, and consequently greater concern about falling as compared with those who have a better perception of health. Fear of falling has been associated with parameters of balance and gait, history of falls, reduced functional capabilities and, in some cases, with unnecessary restriction of participation in physical and social activities (Dalbaere et al., 2010). Freire (2009) showed that older people who reported fear of falling and restriction of activities related to fear of falling had higher scores of FES-I (lower self-efficacy or lower confidence at avoiding falls) and worse self-perceived health, which supports the results of this study. The author concluded that the restriction of activities because of fear of falling have negative effects on functional capacity and psychological aspects for older people. Consequently, this leads to poor quality of life and social isolation of these individuals.

Silva and Menezes (2007) showed an association between perceived health and several socio-demographic and health conditions such as: income, presence of angina, history of stroke, among others. Alves and Rodrigues (2005) also assessed associated factors with the perception of health and found that variables such as gender, presence of chronic diseases and functional capacity are the most prevalent determinant of self-perceived health in older individuals. Unfortunately these factors (e.g., diabetes, hypertension, and hypercholesterolemia) were not assessed in the present study, which limits our discussion of results. On the other hand, the most prevalent health conditions had similar frequency between both groups (Table 1), regardless of physical activity participation. This suggests that the biological changes resulting of the aging process per se, as well as, the nutritional habits of life can be major factors for triggering these health risk factors in older individuals. In this case, physical activity can be a preventive strategy to protect against the consequences of mortality in some cases, in addition to reduce the risk for falls among older people.

Public service investments for effective and integrated actions should address the main determinants of selfperceived health by older people, which can contribute to the promotion of health, wellness and quality of life (Alves 
\& Rodrigues, 2005). Programs for prevention and assistance of older people designed to protect their functional capacities also should be encouraged as an effective way to reduce the fear of falling (Dalbaere et al., 2010). This study suggests that the concern with falls can be reduced in the older individuals who take part in physical activity programs with minimum frequency of twice a week (45-min session each week), which usually is offered at the BHU organization. Siqueira et al. (2007) suggest that public policies for primary care services need to establish physical exercise programs for older people as effective measures for decreasing the risk for falls. Falls among older people have high incidence and result in serious consequences for their health. Sometimes health programs in public care services value prevention/education of the cardiovascular diseases without stimulating the practice of exercises on a regular basis.

Some secondary measures in this study used participants' self-report, specifically with regard to status of health conditions and history of falls, which raises the question about memory accuracy. To ensure an accurate self-assessment in the questionnaire, we employed the Mini-exam of Mental State to exercise the exclusion criterion of participants for possible cognitive impairments. Another limitation of this study included the non comparison between genders ( 18 men and 67 women). The transversal design herein employed limited us to establish the cause-effect relationship between the variables (health condition and fear to falling). The present study did not assessed influences of specific categories of physical activity, as well its intensity, frequency and duration of training on the selected variables, as well as the influence of others factors (e.g., age, health status and history of falls). Further studies should address these limitations.

\section{Conclusions}

The results of this study showed that fear of falling were significantly higher in the older adults who did not engage in regular physical activity programs, especially among those who perceived their health as poor or very poor. Fear of falling is considered a risk factor for falls and a determining factor for the restriction on functional activities. Some results of the present study are in agreement with the literature. However, few recommendations with regard to perceived health and its association with physical activity were addressed in the specific literature. The poor perception of health may influence individuals' adherence to preventive practices to ensure healthy lifestyles. The results of this study have important implications for making clinical decisions in prevention or rehabilitation of older people, and they justify recommendations to the public health system.

\section{References}

Alves, L. S. \& Rodrigues, R. N. (2005). Determinants of self-rated health among elderly persons in São Paulo, Brazil. Revista Panamericana de Salud Publica, 17(5/6), 333-41. http:// dx.doi.org/10.1590/S1020-49892005000500005.

Borges, M. R. D. \& Moreira, A. K. (2009). The Influences of the physical activity practice on aging: A comparative study on the autonomy level for performance on DLAs and IADLs between the physically active and sedentary elderly. Motriz 15(3), 562573. Retrieved from http://www.periodicos.rc. biblioteca.unesp.br/index.php/motriz/article/view/2136/2473.

Brazilian Institute of Geography and Statistics (2009). Projeções da população. Retrieved from www.ibge.gov.br.

Brucki, S. M. D., Nitrini, R., Caramelli, P., Bertolucci, P. H. F., \& Okamoto, I. H. (2003). Suggestions for utilization of the minimental state examination in Brazil. Arquivos de NeuroPsiquiatria, 61(3B), 777-781. http://dx.doi.org/10.1590/S0004282X2003000500014.

Camargos, F. F. O., Dias, R. C., Dias, J. M. D., \& Freire, M. T. F. (2010) Cross-cultural adaptation and evaluation of the psychometric properties of the Falls Efficacy Scale International Among Elderly Brazilians (FES-I-BRAZIL). Revista Brasileira de Fisioterapia, 14(3), 237-243. http:// dx.doi.org/10.1590/S1413-35552010000300010.

Dalbaere, K., Close, J. C. T., Brodaty, H., Sachdev, P. L., \& Lord, S. R. (2010). Determinants of disparities between perceived and physiological risk of falling among elderly people: cohort study. British Medical Journal, 18(341), p. C4165. http:// dx.doi.org/10.1136/bmj.c4165

De Vitta, A., Neri, A. L., \& Padovani, C. R. (2006). Saúde percebida em homens e mulheres sedentários e ativos, adultos jovens e idosos. Salusvita, 25(1), 23-34. Retrieved from http:// www.usc.br/biblioteca/salusvita/salusvita_v25_n1_2006 _art_02.pdf.

Freire, M. T. F. (2009). Características associadas à restrição de atividades por medo de cair em idosos comunitários. (Master's dissertation). Universidade Federal de Minas Gerais. Retrieved from http://www.eef.ufmg.br/mreab/documentos_ new/Dissertpdf/DisMariaTeresaFreire.pdf.

Gerez, A. G. Velardi, M., Câmara, F. M. \& Miranda, M. L. J. (2010). Physical Education and Aging: a reflexion on the need of a new approach and practice. Motriz, 16(2), 485-495 Retrieved from http://www.periodicos.rc.biblioteca.unesp.br/index.php/motriz/ article/view/3075/3005.

Jorstad, E. C., Hauer, K., Becker, C. \& Lamb, S. E. (2005). Measuring the psychological outcomes of falling: a systematic review. Journal of the American Geriatrics Society, 53(3), 501-510. mar. 2005. Retrieved from http://dx.doi.org/10.1111/ j.1532-5415.2005.53172.x.

Kempen, G. I. J. M., Van Haastregt, J. C. M., McKee, K. J., Delbaere, K. \& Zijlstra, G. A. R. (2009). Socio-demographic, health-related and psychosocial correlates of fear of falling and avoidance of activity in community-living older persons who avoid activity due to fear of falling. BMC Public Health, 9, 170. http://dx.doi.org/10.1186/1471-2458-9-170.

Legters, K. (2002). Fear of falling. Physical Therapy 82(3) 264272. Retrieved from http://ptjournal.apta.org/content/82/3/ 264.full.pdf+html.

Lopes, K. T., Costa, D. F. Santos, L. F., Castro, D. P. \& Bastone, A. C. (2009). Prevalence of fear of falling among a population of older adults and its correlation with mobility, dynamic balance, risk and history of falls. Revista Brasileira de Fisioterapia, 
13(3), 223-229. http://dx.doi.org/10.1590/S1413-35552009 005000026

Lord, S.R., Menz, H.B. \& Tiedemann, A. (2003) A physiological profile approach to falls risk assessment and prevention. Physical Therapy, 83(3), 237-252. Retrieved from http:// ptjournal.apta.org/content/83/3/237.full.pdf+html.

Municipal Secretary of Aging Affairs (2010). Perfil da população idosa de Londrina. Prefeitura Municipal de Londrina. Retrieved from http://home.londrina.pr.gov.br/idoso/download/ perfil_idoso_2009.pdf.

National Health Council, (1996). Diretrizes e normas regulamentadoras da pesquisa envolvendo seres humanos. Resolução 196/96. Retrieved from http://conselho.saude. gov.br/comissao/conep/resolucao.html.

Perracini, M. R. \& Ramos, L. R. (2002). Fall-related factors in a cohort of elderly community residents. Revista de Saúde Pública, 36(6), 709-716. http://dx.doi.org/10.1590/S0034-8910 2002000700008.

Scheffer A. C., Schuurmans M. J., van Dijk, N., van der Hooft, T., $\&$ de Rooij, S.E. (2008). Fear of falling: measurement strategy, prevalence, risk factors and consequences among older persons. Age and Ageing, 37, 19-24. doi: 10.1093/ageing/afm169.

Silva, E. C., Duarte, N. B., \& Arantes, P. M. M. (2011). Estudo da relação entre o nível de atividade física e o risco de quedas em idosas. Fisioterapia e Pesquisa, 18(1), 23-30. Retrieved from http://www.scielo.br/pdf/fp/v18n1/05.pdf.

Silva, T.R. \& Meneses, P.R. (2007). Self-rated health: a study in an elderly low income population of São Paulo. Revista de Medicina, 86(1), 28-38. Retrieved from http://medicina.fm. usp.br/gdc/docs/revistadc_96_p.28-38\%20861.pdf.

Silvestre, J. A. \& Costa Neto, M. M. (2003). Approach to the elderly in family health programs. Cadernos de Saúde Pública, 19(3), 839-847. http://dx.doi.org/10.1590/S0102-311X2003000300016.

Siqueira, F. V., Facchini, L. A., Piccini, R. X., Tomasi, E., Thumé, E. Silveira, D. S. Vieira, V., \& Hallal, P. C. (2007). Prevalence of falls and associated factors in the elderly. Revista de Saúde Publica, 41(5), 749-756. http://dx.doi.org/10.1590/S003489102007000500009.

Yardley, L. \& Smith, H. (2002). A prospective study of the relationship between feared consequences of falling and avoidance of activity in community-living older people. The Gerontologist, 42(1), 17-23. http://dx.doi.org/10.1093/geront/42.1.17.

Yardley, L. Beyer, N., Hauer, K., Kempen, G., Piot-Ziegler, C., \& Todd, C. (2005). Development and initial validation of the falls efficacy scale-international (FES-I). Age and Ageing, 34(6), 614-619. http://dx.doi.org/10.1093/ageing/afi196

\section{Authors' note}

Carolina Kruleske da Silva is affiliated with the Physical Therapy Department, Northern University of Paraná, UNOPAR, and has a master's degree in Rehabilitation Sciences, State University of Londrina/Northern University of Paraná, UNOPAR, Londrina, PR, Brasil.

Celita Salmaso Trelha is affiliated with the Physical Therapy Department, State University of Londrina (UEL) and the Master Program in Rehabilitation Sciences, State University of Londrina/ Northern University of Paraná, UNOPAR, Londrina, PR, Brasil.

Rubens Alexandre da Silva Junior is affiliated with the Research Center in Health Sciences, Northern University of Paraná, UNOPAR, and with the Master's Program in Rehabilitation Sciences, State University of Londrina/Northern University of Paraná, UNOPAR, Londrina, PR, Brasil.

\section{Correspondence to:}

Carolina Kruleske da Silva

Northern University of Paraná, UNOPAR, Departament of Physical Therapy

Av. Paris 675, Jd. Piza, 86041-140, P.O. Box 401, Londrina, PR, Brazil Phone: +55 (43) 33717962

Email: carolk_fisio@yahoo.com.br

Manuscript received on February 6, 2013

Manuscript accepted on May 17, 2013

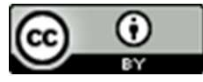

Motriz. Journal of Physical Education. UNESP, Rio Claro, SP, Brazil, eISSN: 1980-6574, is licenced under a Creative Commons License, Version 3.0. 